\title{
Preventivna vloga pozitivnih psihosocialnih odnosov v šoli
}

Zora Rutar Ilc

prispevku bom osvetlila različne vidike psihosocialnih odnosov v šoli in njihov vpliv na učence, njihovo počutje ter razredno klimo, vključno $s$ pojavom nasilnega vedenja, nato pa na tem utemeljili šolsko strategijo spodbudnega in varnega učnega okoljar kot enega ključnih zaščitnih oz. preventivnih pristopov.

Problematiko nasilja v šoli bomo torej v izhodišču umestili v širši kontekst psihosocialnih odnosov in klime ter povezali obravnavanje vedenjsko in osebnostno problematičnih učencev s širšo - interakcijsko oz. socialno ravnijo. Ali kot pravi Muršič:

/N/nasilje ni nekaj objektivnega in absolutnega, temveč je vselej posledica interpretiranj in vrednotenj, ki naj vselej upoštevajo tudi interakcijski, situacijski, ožji socialni in širši družbeni kontekst posameznikovega nasilnega ravnanja. Takšno kontekstualiziranje nasilja se bistveno razlikuje od tistih (preozkih, etiketirajočih) pristopov, ki v nasilnem vedenju posameznika najraje vidijo zgolj značilni izraz njegove »nasilne strukture osebnosti< in drugih individualnih lastnosti. S postavljanjem nekega spornega ravnanja v kontekst si šele odpremo možnosti za celovito razumevanje pa tudi obravnavanje in preprečevanje (Muršič, 20I2: 9).

Ključni institucionalni prizorišči, dodaja Muršič, lahko pa tudi dejavnika nasilja, sta pri tem družina in šola. Obetavno je, da lahko šola $s$ svojimi praksami in intervencami hkrati blaži in popravlja učinke družinskega in širšega socialnega nasilja. Raziskave kažejo, da obstajajo šole,

I Več o razumevanju in opredelitvah tega termina v Varno in spodbudno uino okolje (2O19), ur. Tomaž Kranjc, Šola za ravnatelje, Ljubljana. 
čeprav umeščene $\mathrm{v}$ skupnosti z veliko stopnjo nasilja, ki niso bolj obremenjene z njim kot šole iz bolj pozitivnih skupnosti. To potrjuje, da s svojimi socialnimi in organizacijskimi značilnostmi blažijo negativne vplive nasilne skupnosti. Muršič s tem v zvezi citira tudi Deklevo: »Kot razmeroma razmejen institucionalen sistem je šola možno oprijemališče intervencij, ki naj bi imele za namen povečati učinkovitost socialne kontrole« (Dekleva, 1996: 135, povzeto prav tam: 13).

$\mathrm{V}$ nadaljevanju se bomo zato sklicevali na vrsto avtorjev, ki poudarjajo, kako lahko šola in učitelji s spodbudno klimo, gradnjo kakovostnih odnosov, prispevanjem $\mathrm{k}$ čustvenemu in socialnemu učenju ter $\mathrm{z}$ jasno kulturo neodobravanja nasilja in pozitivnim vrednostnim sistemom učinkujejo kot varovalni dejavnik pred različnimi pojavi nasilja.

\section{Celostni pristop $\mathrm{k}$ zagotavljanju spodbudnega in varnega učnega okolja kot dejavnik prevencije nasilja}

Šola je varovalni dejavnik tako na sistemski kot na psihološki oz. psihosocialni ravni. Na sistemski ravni je varovalni dejavnik s tem, da si na sistematični način prizadeva za kulturo nenasilja in sodelovanja ter spodbudnega in varnega učnega okolja. To lahko poteka ob formalnih in neformalnih priložnostih, pri pouku predmetov in kroskurikularno, redno in ob enkratnih dogodkih ... Na psihološki oz. psihosocialni ravni pa varovalno deluje s spodbudno razredno klimo in ustreznim vodenjem razreda, $s$ skrbjo za dobro počutje in psihično blagostanje učencev in učiteljev, s prepoznavanjem otrok $\mathrm{v}$ stiski ter tistih $\mathrm{z}$ neželenim vedenjem ter $s$ pravočasno odzivnostjo in ustrezno podporo za vse, ki to potrebujejo.

V nadaljevanju bom podrobneje razčlenila oba vidika, najprej psihološkega, v luči psihosocialnih konceptov, in sistemskega, nato pa nakazali nekaj praks, ki lahko kot kombinacija psihosocialnih praks in sistemskega oz. celostnega pristopa na ravni šole, razreda in pri delu s posameznikom prispevajo h kulturi nenasilne skupnosti in/oz. k preprečevanju nasilja. Za kulturo nenasilne skupnosti bom $\mathrm{v}$ nadaljevanju uporabljala predvsem afirmativne termine, kot so kultura dobre skupnosti (npr. po Bečaju) in spodbudno ter varno učno okolje (izraz, ki se pojavlja $\mathrm{v}$ nacionalnih in mednarodnih dokumentih).

\section{Psihosocialni dejavniki v šoli in njihov kompleksni preplet} V slovenski literaturi je vpliv psihosocialnih dejavnikov tako na delovanje posameznikov kot skupin in skupnosti dobro opisan in raziskan. V našem prispevku se bomo naslonili predvsem na nekatere modele, predstavljene $\mathrm{v}$ delih slovenskih avtoric. To so: 
- model psihosocialnih odnosov Peklajeve in Pečjakove, med drugim zasnovan na študiji in modelu povezav med učenčevim vedenjem in odnosi v šoli z občutjem pripadnosti in zavzetosti Juvonena, modelu medosebne socialno vedenjske kompetentnosti znotraj šolskega konteksta Walkerja, Irvina, Noella in Singerja ter modelu odnosov med učiteljem in učenci Piante (Peklaj in Pečjak, 2015: II),

- model prosocialnega razreda (Jennings in Greenberg 2009, po Vidmar, 2018) in

- procesni model odnosov med socialnim kontekstom, selfom, vedenjem in izidi (Connell in Wellbron, 1991, po Košir 2013: I8).

Vse omenjene avtorice in avtorji, ki jih povzemajo, dokazujejo, da so učiteljeve socialne in čustvene kompetence ključne za kakovostne odnose $\mathrm{z}$ učenci, za razvoj socialnih in čustvenih kompetenc pri učencih ter za učenčevo učenje in razvoj na splošno. Hkrati pa so pomembne tudi za (psihično) blagostanje učiteljev, kajti ščitijo jih pred stresom in izgorelostjo. V naslednjih razdelkih bomo podrobneje razčlenili, s katerimi konkretnimi vedenji in značilnostmi komunikacije učitelj vpliva na odnos z učenci in celo na odnose med učenci ter kako lahko te učinke dodatno okrepi s premišljenim vodenjem razreda z namenom dobre oz. vključujoče klime. Prikazali bomo tudi dve orodji, s katerima si lahko pomaga pri refleksiji in krepitvi želenega odnosa.

Peklaj in Pečjak kot enega ključnih odnosov v šoli izpostavita odnos učitelja do učencev in navajata številne raziskave o pomembnosti učiteljevih pričakovanj in spodbud za učenčevo uspešnost in počutje. Tako navajata, da povezanost odnosov učitelja $\mathrm{z}$ učenci s kognitivnimi spremenljivkami v povprečju pojasni skoraj Io \% variance $(\mathrm{r}=0,3 \mathrm{I})$, največ za kritično/kreativno mišljenje in dosežke. Povezanost s čustveno vedenjskimi spremenljivkami pa je še nekoliko večja $(\mathrm{r}=0,35)$ z najvišjimi povezavami (s skoraj $20 \%$ pojasnjene variance) pri sodelovanju in zadovoljstvu učencev, z zmernimi pa tudi pri preprečevanju osipa, samoučinkovitosti/ duševnem zdravju, pozitivni motivaciji in socialni povezanosti (Peklaj in Pečjak, 2015: 8I-88).

Raziskave so potrdile, da so odnosi z učiteljem eden ključnih dejavnikov učenčeve vključenosti, »ki se kaže v njegovem interesu za učenje in delo v šoli, manjšem izražanju jeze ter večjem vlaganju napora, večji pozornosti in daljšem vztrajanju pri nalogah « (Peklaj in Pečjak, 2015: 77). Izkazalo se je tudi, da je v višjih razredih, ko učenci postanejo bolj kritični do učitelja, njegov pozitiven odnos do učencev še pomembnejši za vzdrževanje discipline in zavzetosti učencev za učenje. Tudi dve slovenski raziskavi sta potrdili, da je učiteljeva podpora povezana $\mathrm{z}$ učenčevo notranjo 
motivacijo, njegovo samoučinkovitostjo (Puklek Levpušček, 2001: 78) in celo z učno uspešnostjo pri matematiki (Puklek Levpušček in Zupančič, 2009).

Med faktorje pozitivnega odnosa učiteljev z učenci Peklaj in Pečjak, sklicujoč se na Juvonena, uvrščata med drugim: zaznano podporo, ravnanje s konflikti, odvisnost ter zaznano pravičnost, kar je moč izmeriti z različnimi vprašalniki in lestvicami (npr. za zaznavanje učiteljeve podpore). Peklaj in Pečjak osvetlita tudi vprašanje, kako socialni odnosi motivirajo učence za šolsko delo in kako učenci v učnih situacijah usklajujejo socialne motive s sodelovanjem. Sklicujoč se na model Walkerja in drugih poudarita, kako manj prilagojeno vedenje učencev vpliva na razred in na odnose $\mathrm{z}$ učiteljem: prilagojeno vedenje učencev vodi v sprejetost in oporo s strani vrstnikov in učiteljev ter krepi učno uspešnost, medtem ko neprilagojeno vedenje vodi k zavračanju s strani obojih in $\mathrm{k}$ nižanju učne uspešnosti in aspiracij. Iz tega izpeljeta, da šolsko prilagojenost napovedujejo tako interakcije med učitelji in učenci kot tudi interakcije med učenci. Povzemata tudi izsledke domače raziskave, ki je potrdila, da socialna vključenost deluje kot pomemben varovalni dejavnik.

Ključno pri razlaganju prepleta psihosocialnih dejavnikov in njihovih raznolikih učinkov je torej, da gre za kompleksne odnose povezav, krožne in spiralne, ko sprememba enega dela vzvratno vpliva na vse ostale. Zato to, kako učitelj s svojo komunikacijo, zgledom in celotnim svojim odnosom vpliva na razred, na odzivanje učencev, vzvratno vpliva na njegovo doživljanje razreda in odnosov ter na njegove naslednje interakcije in obratno. Kot slikovito opišeta Peklaj in Pečjak:

Učiteljeva vključenost, spodbujanje učencev, oblikovanje spodbudnega učnega okolja, v katerem učenci zaznavajo, da so cenjeni in spoštovani, vplivajo na večjo učenčevo vključenost v delo v oddelku, na vlaganje več truda, vztrajanje. Vse to pa spet vpliva nazaj na učitelja, da se tudi on še bolj vključuje v ta odnos. Ta odnosna spirala povratnih zank se tako lahko zavrti v pozitivno smer, v nasprotnem primeru, ko se začne odnos z negativnimi povratnimi zankami, pa se lahko obrne tudi v negativno smer (Peklaj in Pečjak, 20I5: Io8).

Vidmar in soavtorice (2018) s tem v zvezi omenjajo, kako so učitelji v svoji praksi pogosto izpostavljeni čustveno provokativnim situacijam, kot je npr. žaljivo vedenje učencev ali različne oblike odpora in nesodelovanja, in poudarjajo, da razvite socialne in čustvene kompetence (npr. zmožnost samouravnavanja) pripomorejo $\mathrm{k}$ bolj učinkovitemu obvladovanju vsakodnevnih tovrstnih izzivov. Tudi one poudarijo, da pa se dogaja tudi 146 
obratno in da se zaradi šibkeje razvitih socialnih in čustvenih kompetenc učiteljev pojavijo slabi odnosi z učenci in težave z vodenjem razreda:

To lahko pripelje do slabše klime (bodisi kaznovalne bodisi razpuščene), v kateri ni mogoče dosegati zastavljenih učnih, socialnih, čustvenih ciljev. Pri učitelju pa se lahko pojavi občutek neučinkovitosti in čustvene izmučenosti, zaradi česar je njegovo soočanje z vsakodnevnimi socialnimi in čustvenimi izzivi oslabljeno, kar še poslabša odnose v razredu in kakovost vodenja razreda, klimo in doseganje ciljev (ustvari se, začaran krog izgorelosti').

V zvezi s kompleksnostjo odnosov med učitelji in učenci Pianta navaja

več elementov, ki se nanašajo na značilnosti obeh udeležencev (učitelja in učenca), na predstave udeležencev o odnosih, procese izmenjave informacij med udeleženci (interaktivna vedenja) in vplive sistema, v katerega so vključeni odnosi (Peklaj in Pečjak, 20r5: 87).

Te elemente je moč preveriti z različnimi instrumenti (npr. za merjenje učiteljeve samoučinkovitosti, ugotavljanje prepričanj, pričakovanj in predstav ter nenazadnje učiteljevih osebnostnih značilnosti). V nadaljevanju jih bomo obravnavali pod terminom odnosna kompetenca učitelja in jih podrobneje razčlenili.

Na pomembno vlogo socialnih vidikov delovanja učencev in njihovega kompleksnega prepleta za šolsko prilagojenost in učinkovito ter uspešno učenje opozarja tudi Košir:

Razumevanje socialnega konteksta tervzajemnih medosebnih in skupinskih procesov, ki se dogajajo v šoli in v razredih, predstavlja pomemben vidik tudi za razumevanje učnega vedenja učencev (Košir 20I3: II).

Pri tem izpostavlja ključno vlogo učiteljevega odnosa z učenci oz. pomena njegove podpore za šolsko prilagojenost učencev. Sklicujoč se na več avtorjev in raziskav, ovrže stereotip, da naj bi bili prijazni učitelji manj uspešni pri doseganju učnih ciljev. Prav nasprotno: kot smo pokazali z navedbami številnih avtorjev in raziskav in kot bomo utemeljili ob osvetljevanju odnosne kompetence v naslednjem razdelku, je pozitiven, spodbuden odnos učiteljev do učencev odločilen za dober stik in odnose z njimi, za boljšo klimo in za večjo učno uspešnost. 


\section{Odnosna kompetenca učitelja - ena ključnih učiteljskih kompetenc in psihosocialnih dejavnikov v šoli}

Nakazali smo že, kako zelo pomemben je odnos učitelja do učencev in kolikšen vpliv ima na različne vidike delovanja in doživljanja učencev, celo na njihove učne dosežke ter tudi na klimo in počutje v razredu. Hattie je ugotovil, da je odnos učitelja do učencev eden od najpomembnejših dejavnikov pri dosežkih, prav tako ga kot najpomembnejšo od učiteljskih kompetenc pojmujeta Pianta in Juul. Juul pri tem navaja raziskavo, ki kot temeljne kompetence učitelja opredeljuje akademsko, didaktično, vodstveno in odnosno kompetenco (Juul, 2014: 35): »Pouk je pomemben, toda še pomembnejša je odnosna kompetenca« (prav tam: 104);

Odnosna kompetenca je sposobnost, da otroka zaznava kot individuum; takega, kakršen je; da svoje obnašanje prilagodi temu, ne da bi se odpovedal vodenju (prav tam: II2).

Gre za to, da smo z otrokom v pristnem stiku in vzamemo resno njegove misli ter občutja. Ali kot Juula povzema Malešević:

Če posedujemo odnosno kompetenco, ljudi vodimo tako, da se vsi počutijo dobro in brez občutka krivde. $S$ tem preidemo iz stare kulture poslušnosti v novo kulturo odgovornosti (prav tam) (Malešević, 2or8: 19).

Vrsta raziskovalcev je ugotavljala, katere so osebne in profesionalne značilnosti učinkovitega učitelja, in prekrivanje je veliko, zajema pa strokovnost in dobro pripravljenost, pozitiven odnos do poučevanja in učencev, dostopnost, spodbudnost, visoka, a realistična pričakovanja in verjetje $\mathrm{v}$ učence, oseben pristop, učenci se lahko obrnejo nanj, sproščenost in humornost, a hkrati spretno vodenje razreda, iskrenost, samokritičnost, poštenost in druge. Košir tako povzema po Wentzel (1997), da skrbne učitelje učenci opisujejo z značilnostmi, kot so: znajo narediti pouk zanimiv, se pogovarjajo $z$ učenci in jih poslušajo, so pošteni, pravični in zaupanja vredni, preverjajo pri učencih, če so razumeli ali potrebujejo pomoč. Učitelje, ki so jih zaznavali kot neskrbne, pa so učenci opisali takole: spregledajo, prekinjajo, žalijo, spravljajo $\mathrm{v}$ zadrego ali vpijejo na učence, so dolgočasni ali izgubljajo rdečo nit, ne kažejo zanimanja za učence (Košir, 20I3: III).

Pšunder se v svojem delu Disciplina v šoli (2006) pri navajanju dejavnikov, ključnih za pozitivne odnose in preventivno disciplino, sklicuje na Kounina:

Učitelj naj bi si prizadeval z učenci vzpostaviti pozitivno interakcijo $s$ poučevanjem tako, da bi jim prisluhnil, jih spodbujal, spoznaval njihove 
prednosti, jim pomagal, pokazal interes za njihovo življenje /.../, za njihove težave in jim sporočal, da jim je naklonjen, jih spoštuje, ceni in da mu je mar za njihovo dobro. (prav tam: 17, I08).

Pomembno vlogo pri tem imajo spodbude in pohvale ter verodostojna in spodbudna povratna informacija, ki učenca podpre pri izboljševanju. Podobno navaja Charlesa (1996), da k dobrim in kakovostnim odnosom $z$ učenci prispevajo npr. prijaznost, pozitivna drža, sposobnost poslušanja, iskreno zanimanje za učence in njihove interese in dosežke, sposobnost dajanja pristnih komplimentov, redno namenjanje pozornosti učencem oz. vzpostavljanje zaupanja, pripravljenost pomagati, pozitivna visoka pričakovanja v zvezi z delom učencev oz. verjetje v njihove zmožnosti ter omogočanje razprav, ki vključujejo vse učence (Pšunder, 2006: II5-II6).

Večina avtorjev izrecno poudarja, da je za odnos z učenci prvi odgovoren učitelj kot odrasli. Kljub drugačnemu, tudi neprimernemu, odzivanju ali vedenju učencev je njegovo pedagoško poslanstvo ostati umirjen, spoštljiv in ravno s tem učencem dajati zgled ter omogočati spodbudno okolje za izbiro bolj ustreznih vedenj. Te značilnosti in iz njih izvirajoča vedenja smo, opirajoč se predvsem na Marzana (Marzano in Marzano, 2010: 113-154; Marzano in Simms, 2013: 186-207), zajeli v opomniku za dobro klimo, ki ga na kratko predstavljamo v nadaljevanju. Poglavje o odnosni kompetenci zaokrožujemo z ugotovitvijo Marzana in Marzana iz metaanalize, da

da predstavlja kakovost odnosov med učiteljem in učencem temeljni kamen za vse druge vidike vodenja razreda. Naša metaanaliza dokazuje, da imajo v povprečju učitelji, ki imajo zelo kakovostne odnose z učenci, skozi vse leto 3I odstotkov manj disciplinskih problemov in primerov kršenja pravil ter $s$ tem povezanih težav kot učitelji, ki takih odnosov $s$ svojimi učenci nimajo (Marzano in Marzano, 2010: 55 ).

Opomnik za dobro klimo z naslovom Kako skrbim za dobro razredno klimo (Rutar Ilc, 2017) zajema naslednja področja, od katerih je vsako opisano z več dimenzijami, izraženimi v prvi osebi ednine (pri vsakem področju jih na tem mestu navajamo le nekaj):

- Skrb za varnost, orientacijo, potrditev in sprejetost (npr.: Prizadevam si za spoznavno, čustveno in socialno varno učno okolje; spremljam počutje učencev; kažem, da mi je mar za učence; omogočam, da izražajo svoje mnenje in občutke; izražam odobravanje ob uspehih; sporočam, da je spoštovanje cenjeno; spodbujam empatijo in prosocialnost ...); 
- Negovanje spoštljive, spodbudne in odprte komunikacije (npr. vzpostavljam sproščen odnos, ko je to primerno, in odločnost, ko je to potrebno; z učenci komunikciram odkrito, a vljudno, spoštljivo in sprejemajoče ...);

- Dajanje podpore in pozitivna pričakovanja (npr. izražam svoja pozitivna pričakovanja $\mathrm{v}$ zvezi z napredkom in uspešnostjo in omogočam priložnosti, v katerih se učenci lahko izkažejo; kažem, da zaupam in verjamem v učence; dajem možnosti izbire ...);

- Sprejemanje različnosti (sprejemam razlike; ozaveščam svoje zadržke/predsodke do posameznikov ali skupin ...);

- Skrb za posebne potrebe (podpiram celostno vključenost učencev, vključnost $s$ čustvi, vključujem veččutno predstavnost; razlikujem med vedenjem in uspehom ter osebno vrednostjo ...);

- Skrb za pravičnost (zavem se, kadar nisem pravičen; pri sebi zaznavam negativna občutja do posameznikov; poiščem razloge; vzamem si čas za premislek ...);

- Upravljanje konfliktov (tudi v kriznih primerih si prizadevam za uporabo spoštljivega tona; omogočam varno okolje za poslušanje in argumentiranje vseh vpletenih ...);

- Skrb za psihofizično blagostanje (zaznam morebitno preobremenjenost posameznikov in skupin; zaznam stiske; zavedam se meja svoje odgovornosti in vpliva ...) (prav tam: 12, 13).

Opomnik lahko učiteljem služi za načrtovanje in samorefleksijo $\mathrm{v}$ različnih časovnih intervalih: pred učno uro za naravnavanje, po njej za refleksijo, pred začetkom šolskega leta kot opora za načrtovanje, na koncu šolskega leta za refleksijo ali primerjavo začetnega s končnim stanjem, lahko pa služi tudi kot opora za kolegialna opazovanja in podpiranje ter kot osnova za dolgoročni profesionalni razvoj. $\mathrm{V}$ ta namen so opomniku dodani primeri vprašanj, diferencirani za izkušene učitelje in začetnike, $s$ pomočjo katerih učitelji v samorefleksiji ali v vodenem pogovoru s kolegom lažje ozavestijo nekatere manj učinkovite vzorce vodenja razreda, hkrati pa lahko načrtno krepijo želene vidike oz. veščine.

\section{Vloga potreb v odnosih}

Če smo doslej osvetljevali predvsem različne vidike odnosov med učitelji in učenci, njihovo kompleksnost oz. prepletenost ter različne vrste učinkov, med drugim povezanost socialnih dejavnikov $s \mathrm{t}$. i. šolsko prilagojenostjo, si bomo v nadaljevanju ogledali, naj kaj pri učencih ti odnosi delujejo tako, da povzročajo omenjene učinke. Dotaknili se bomo konceptov občutja kompetentnosti in mehanizma navezanosti ter $v$ najširšem smislu 
zadovoljevanja temeljnih psihosocialnih potreb. Kot zapiše Malešević, odnose učitelj-učenec lahko pojasnimo z vidika učenčevih potreb, ki jih ta v tem odnosu zadovoljuje (Erskine, 2002; v Miljkovic, 2010); identificiranih je 8 pomembnih odnosnih potreb, ki se lahko zadovoljijo v odnosu $s$ pomembnimi drugimi. To so potreba:

I) po varnosti,

2) po doživljanju upoštevanja, potrjevanja in pomembnosti,

3) po sprejemanju s strani stabilne, zanesljive in zaščitniške osebe,

4) po priznavanju osebne izkušnje,

5) po samoizražanju,

6) po potrebi vplivanja na druge,

7) po dajanju iniciative ter

8) po izražanju naklonjenosti in ljubezni (Malešević, 20I8: I8).

Več slovenskih avtoric povzema Ryana in Decija, ki zatrjujeta, da je šolska prilagojenost optimalna, kadar so zadovoljene tri temeljne potrebe: potreba po kompetentnosti, potreba po avtonomiji ter potreba po pripadnosti in povezanosti. $\mathrm{K}$ tem trem potrebam lahko učitelji prispevajo tako, da učencem omogočijo izkušanje kompetentnosti, avtonomije in povezanosti (npr. jih podprejo pri izkazovanju njihovih močnih področij in dosežkov, jih spodbujajo in do njih gojijo pozitivna pričakovanja, opazijo in pohvalijo njihove dosežke ter jim omogočajo priložnosti za izbiro in odločanje; Peklaj in Pečjak, 2015; Košir, 2013; Malešević, 2018). To pa vodi $\mathrm{k}$ občutkom kompetentnosti, zaupanja $\mathrm{v}$ lastne zmožnosti in do $\mathrm{s}$ tem povezanega občutja lastne vrednosti in je povezano s prej opisano odnosno kompetenco.

Tudi Connel in Wellborn (1991, povzeto po Peklaj in Pečjak, 20I5: 13) sta ugotovila, da sta za zavzetost za šolo ključni občutji kompetentnosti in avtonomnosti, Juvonen in Wentzel (1996, povzeto prav tam) pa, da je potreba po pripadnosti povezana s storilnostno motivacijo. Ali kot pravita Peklaj in Pečjak: »Gre za vprašanje, kako socialni odnosi motivirajo učence za šolsko delo « (Peklaj in Pečjak, 20I5). Učna in socialna kompetentnost prispevata $\mathrm{k}$ občutjem sprejetosti in zaupanja v lastne zmožnosti, vodita $\mathrm{k}$ boljši samopodobi in krepita dober položaj učenca in obratno, neprilagojeno vedenje $\mathrm{v}$ odnosu do vrstnikov ali sošolcev $\mathrm{v}$ povezavi $\mathrm{s}$ slabšim učnim uspehom praviloma prispeva k zavračanju, slabši učni uspešnosti in zniževanju aspiracij (Peklaj in Pečjak, 2015).

Predpostavke o pomembnosti občutja povezanosti in s tem povezane pripadnosti ter sprejetosti predstavljajo $\gg$ najpogostejše teoretsko ozadje za večino raziskav, ki so preučevale različne vrste socialnih odnosov v šolskem kontekstu« (Košir, 2013: 13). Košir v svoji knjigi posveti posamezna 
podpoglavja socialnim kontekstom, ki na sistematičen način spodbujajo kompetentnost in avtonomijo učencev ter njihovo povezanost $\mathrm{z}$ drugimi (prav tam: 18-22). Natančno tudi osvetli pomen potrebe po pripadnosti in njeno povezanost $s$ vključenostjo oz. socialnimi interakcijami ter samospoštovanjem (prav tam: 25). Potreba po pripadnosti je ena temeljnih človekovih potreb, ki pojasnjuje različna vedenja v medosebnih odnosih. Opredeljuje jo pogostost zadovoljujočih prijetnih interakcije z manjšim številom ljudmi ter skrb za dobrobit drugega (prav tam). Z drugimi besedami: poraja se iz dobrega stika. Dokazano se nezadovoljenost te potrebe $\mathrm{v}$ večji meri lahko izraža $\mathrm{z}$ antisocialnim vedenjem, pa tudi $\mathrm{z}$ depresijo in drugimi psihičnimi težavami (prav tam: 24). Občutek sprejetosti in pripadnosti, ki izvira iz občutja povezanosti z drugimi, je tudi izvor občutka lastne vrednosti in samospoštovanja in $s$ tem eden najmočnejših zaščitnih dejavnikov pred neželenim vedenjem ter različnimi oblikami agresije in nasilja.

Zato je toliko bolj pomembno načelo, da ima vsak otrok vsaj enega (zanj pomembnega) odraslega, $s$ katerim je v dobrem stiku, ob katerem se počuti varen in sprejet kot osebnost (ne glede na morebitne težave ali iz njih izvirajoče neželene vedenjske vzorce). $V$ tem kontekstu gre zato iskati ključne preventivne dejavnike pred nasiljem. Eno najpomembnejših varoval pred socialno nesprejemljivimi oblikami vedenja je prav to, da imajo učenci pomembnega drugega - odraslega, s katerim so $\mathrm{v}$ dobrem stiku, na katerega se lahko zanesejo ali obrnejo in se z njegove strani čutijo sprejete, torej imajo občutje pripadnosti relevantni osebi. Učitelj ima privilegirano pozicijo tistega odraslega, ki lahko nadomesti nekompetentnega ali odsotnega starša, pri čemer je že omenjena odnosna kompetenca izrednega pomena.

Ob odnosni kompetenci, ki jo v luči zgoraj zapisanega med drugim lahko opredelimo tudi kot ustrezno odgovarjanje na potrebe otrok in mladostnikov, zdaj osvetlimo še ostale dejavnike oz. kompetence učitelja, ki so v strokovni literaturi pripoznani kot vir vplivanja na razredno klimo oz. spodbudno in vključujoče učno okolje ter posredno tudi na pojav ali odsotnost neželenih oblik vedenja.

\section{Drugi dejavniki učiteljevega vpliva na učence in razred}

Podobno kot Juul, ki kot temeljne učiteljske kompetence opredeljuje akademsko, didaktično, vodstveno in odnosno kompetenco, kot smo navedli že zgoraj, model »veliki štirje « (angl. Big four) Knighta (Marzano in Simms, 2013: 13) kot ključna področja učiteljevih kompetenc opredeljuje:

I) vedenje (npr. komunikacijo, pričakovanja, spodbudnost), 
2) vsebinsko znanje (vključno z globinskim vpogledom discipline),

3) poučevalni pristop (npr. model za razmišljanje, zmožnost za postavljanje vprašanj, ki spodbujajo višje miselne procese, uporabo učnih organizatorjev $\mathrm{v}$ podporo učnemu procesu, omogočanje pomena polnih, smiselnih učnih izkušenj),

4) formativno spremljanje.

Do sedaj smo osvetlili predvsem odnosno kompetenco (po Knightu »vedenje «). Strokovnega oz. akademskega, disciplinarnega področja se na tem mestu ne bomo dotikali, ker ima $\mathrm{z}$ vedenjem in psihosocialnimi odnosi najbolj rahlo povezavo, na kratko pa bomo opozorili na tiste vidike didaktične oz. poučevalne kompetence, ki nanj posredno prispevajo. Juul torej govori o didaktični kompetenci, Marzano in Simms pa govorita o dveh vidikih le-te: o poučevalnem pristopu ter formativnem spremljanju. V kakšnem razmerju sta poučevalni pristop in formativno spremljanje in kakšno vlogo imata pri krepitvi pozitivnih psihosocialnih odnosov in spodbudne, vključujoče razredne klime kot enega ključnih preventivnih dejavnikov?

Marzano in Simms poučevalni pristop razumeta v najširšem smislu tega, kako poteka in je didaktično organiziran pouk ter kako spodbuja aktivno vlogo učencev. V zvezi z aktivnostjo je poudarek na vključevanju višjih miselnih procesov učencev z vprašanji in drugimi učnimi aktivnostmi, ki spodbujajo razmišljanje: raziskovanje, sklepanje, utemeljevanje, povezovanje. Ključno je, da je pouk zanimiv, osmišljen, povezan z življenjem, da so učenci vanj aktivno vključeni, da se navezuje na njihovo predznanje in upošteva tudi njihove interese, aspiracije in vedoželjnost.

Prav formativno spremljanje (FS) je zato pristop, ki v najširšem smislu terja takšne učne izkušnje, ki omogočajo učinkovit preplet učenja in spremljanja. Ključni značilnosti sta maksimalna participacija učencev in vrstniško sodelovanje $\mathrm{v}$ vseh ključnih fazah učnega procesa: pri opredeljevanju namenov učenja, načrtovanju učne izkušnje in dejavnosti, pri zastavljanju vprašanj, pri opredeljevanju dokazil za uspešne dosežke in kriterijev presoje zanje ter pri prejemanju in dajanju povratne informacije, vrstniške in samorefleksije. (Holcar in drugi, 2016).

$\mathrm{Na}$ Zavodu Republike Slovenije za šolstvo sistematično razvijamo pristop formativnega spremljanja po različnih poteh: na osnovi mednarodnega povezovanja in opravljenega domačega projekta na to temo poteka nov razvojni projekt s številnimi vključenimi učitelji in šolami, pristop se sistematično predstavlja in uvaja s pomočjo srečanj študijskih skupin, $\mathrm{v}$ zadnjih dveh letih pa se je razširil in nadgradil še v okviru mednarodnega projekta Bridge, glas učencev. Izkušnje pri vpeljevanju in preizkušanju 
formativnega spremljanja so popisane v več različnih publikacijah in člankih, temi sta posvečeni tudi dve tematski številki revije Vzgoja in izobraževanje, organiziranih pa je bilo že več nacionalnih in mednarodnih posvetov. Izkazalo se je, da pristop formativnega spremljanja pod določenimi pogoji zaradi polnega vključevanja učencev v vse faze učnega procesa ključno prispeva $\mathrm{k}$ njihovi večji zavzetosti, refleksiji, avtoregulaciji, samostojnosti in tudi učni uspešnosti, hkrati pa skozi okrepljene vrstniške povezave tudi k boljši klimi, sodelovalnosti in zmanjševanju pojava neželenega vedenja (Holcar in Kregar, 20ı8). Formativno spremljanje tako deluje preventivno tudi na rizične učence, saj se možnosti za njihovo vključenost, osmišljenost pouka in doseganje potrditev in uspešnosti povečajo.

\section{Vodenje razreda kot pomemben zaščitni dejavnik}

$\mathrm{V}$ nadaljevanju se bomo posvetili vodenju razreda kot nadgradnji že opisane odnosne kompetence in kot enemu ključnih dejavnikov preprečevanja ter učinkovitega obravnavanja neželenega vedenja, preden se spremeni $\mathrm{v}$ agresivno ali, v skrajnem primeru, nasilno (torej agresivno, ki je obrnjeno na drugega).

Vodenje razreda različni avtorji vidijo kot enega ključnih dejavnikov, ki vpliva na psihosocialne odnose $v$ razredu, na počutje učencev in na razredno klimo. Povezano je z odnosno kompetenco (z učiteljevim načinom komunikacije in vzpostavljanjem odnosov nasploh) in z didaktično (kako organizira pouk, vrsto aktivnosti, prehode med njimi, kakšne oblike in načina dela uporabi), hkrati pa se nanaša tudi na strategije dela z razredom kot skupino. Peklaj in Pečjak (2015: I09) opozarjata, da

eksperti na področju vodenja razreda poudarjajo, da se je razumevanje vodenja razreda $v$ zadnjem času spremenilo, in sicer iz poudarkov na zagotavljanju discipline, ustvarjanju pravil in kontrole v oddelku v smer zagotavljanja dobrih odnosov v razredu in omogočanja učenja samouravnavanja.

Podobno razvija koncept preventivne discipline in z njim povezanega vodenja razreda Pšunder (2006 in 20II), vodenju razreda kot pomembnemu zaščitnemu dejavniku za vrsto učinkov v razredu pa se posveča tudi Košir (2013).

$\mathrm{Na}$ teh premisah je zato zasnovan tudi tretji zvezek priročnika Vključujoča šola s pomenljivim naslovom: Vodenje razreda za dobro klimo in vključenost (Rutar Ilc, 2017). V njem je predstavljen opomnik Kako skrbim za dobro disciplino, ki je dopolnilo prej opisanega opomnika za dobro klimo in izhaja iz dela o profesionalnem razvoju učiteljev >Coaching 
classroom instruction « Marzana in Simmsove (2013) in iz priporočil slovenskih avtoric (Pšunder, Košir in drugi).

Opomnik in priročnik (Rutar Ilc, 2017: 22, 23) zajemata naslednja področja vodenja razreda, ki je opredeljeno z opisi konkretnih vedenj:

- Vstopanje v razred in pridobivanje pozornosti;

- Spremljanje in vodenje razreda s stopnjevanjem signalov (besedni signali, uporaba premora, razjasnjevanje, sklicevanje na dogovore in odgovornost, napoved posledic, izvajanje dogovorov, timska obravnava);

- Zanimiv in osmišljen pouk;

- Informiranje in izvajanje rutin(e);

- Oblikovanje pravil;

- Odobravanje spoštovanja pravil;

- Vključevanje izključenih.

Za vključujoče vodenje razreda je ključen dober stik učitelja z učenci in $\mathrm{z}$ razredom. Ta je posledica tega, kako dostopen in spodbuden je učitelj, kako komunicira z učenci in jih podpira, kako spoštljiv, korekten in pravičen je do učencev, kakšna pričakovanja izraža in kako kaže zanimanje zanje, ob tem, da hkrati postavlja jasne meje, ki so osmišljene in pojasnjene. Dober stik je učinek vzajemnega zaupanja ter soudeležbe učencev in je najboljša zaščita pred nedisciplino ali različnimi oblikami neželenega vedenja. Celo z učenci, ki izkazujejo najbolj problematične oblike vedenja, je za doseganje učinkov umirjanja in nadomestnega sprejemljivega vedenja najboljši dober stik. Praviloma te učence umiri in ima nanje pozitiven vpliv tista odrasla oseba, ki zna z njim vzpostaviti stik. Tudi kakršnekoli intervence so smiselne le v dobrem stiku.

V literaturi so evidentirani različni stili vodenja, kot so avtoritarni, demokratični in anarhični, direktivni ali pa indirektivni, podporni, inštruktorski ter delegatski (Peklaj in Pečjak, 20I5: II2-II8). Stili vodenja so do neke mere povezani tudi z vzgojnimi stili in prepričanji. V zadnjih letih se v teoriji vzgoje zagovarja preseganje opozicij med avtoritarnim vzgojnim stilom na eni strani ter permisivnim na drugi s t. i. demokratičnim vzgojnim stilom ali konceptom samoomejitvene avtoritete, ki si prizadeva za vzgojo avtonomne, odgovorne, refleksivne, avtoregulativne, empatične, solidarne osebe. Kot osrednji mehanizem takšnega vzgojnega pristopa Kroflič predlaga demokratično dogovarjanje in sprejemanje odločitev na podlagi etične argumentacije, nadgrajene $\mathrm{z}$ empatijo in sočutjem:

/N/amesto formalnopravne utemeljitve pravila, podkrepljene $\mathrm{z}$ argumentacijo ene od etičnih teorij, posežemo po induktivni logiki, ki 
izpostavi spornost dejanja glede na posledice, ki jih lahko storilec sam prepozna ali predvidi pri žrtvi. /.../ / T/a metoda spodbuja razvoj prosocialnosti v smislu usmerjanja pozornosti na dobrobit druge osebe, ki pri sklicevanju zgolj na racionalne argumente in formalni status kršene norme praviloma izostane. Poleg tega se danes krepi zavedanje, da je razvoj prosocialnih emocij, še posebej sočutja, primarnejši dejavnik človekove moralnosti od etičnega presojanja (Kroflič, 20I3: 8; Kroflič, 2010 in 2012).

$S$ preudarnim ravnanjem in vodenjem razreda lahko učitelj vpliva tudi na dejavnike, ki so na videz neodvisni od njega. Vpliva na to, kako se obravnava sprotne konflikte. S spodbujanjem k odprti in spoštljivi komunikaciji ter z zgledom, ki ga daje, lahko vpliva tudi na vrstniške odnose, ki prav tako predstavljajo pomemben dejavnik psihosocialnih odnosov v šoli (Košir, 2013: 30-69; Peklaj in Pečjak, 2015: 213-247). Prav tako lahko vsak učitelj zazna stiske učencev in po svoji moči prispeva $\mathrm{k}$ njihovemu blaženju, kar pomembno prispeva k dobremu počutju in vključevanju ter s tem posredno $k$ preprečevanju nasilnega vedenja.

Ključna dejavnika vodenja razreda sta torej na eni strani dober stik učitelja $z$ razredom ali njegova pristna povezanost $\mathrm{z}$ učenci, na drugi pa dobra strategija vodenja razreda kot skupine. Če se kljub zanimivemu pouku, ki učence vabi v aktivno vlogo, in kljub dobremu stiku z večino učencev pri posameznikih vseeno pojavi neželeno vedenje, učitelju preostane stopnjevanje signalov (navedeno zgoraj, Rutar Ilc, 2017). Učitelj učencu vse bolj jasno sporoča, kaj pričakuje od njega in kakšno vedenje je zaželeno. Priporočljivo je, da učitelj ne reagira pri vsaki najmanjši kršitvi dogovorov ali pravil na vso moč, ampak stopnjuje moč svojih sporočil. Na ta način povečuje manevrski prostor za izboljševanje vedenja, z drugimi besedami, za samouravnavanje. Seveda pa za nekatere učence in situacije ne zadoščajo niti stopnjevanje signalov niti druga vzgojna sporočila, zato uporabimo zahtevnejše tehnike za podpiranje učencev pri uravnavanju čustev in spreminjanju vedenjskih vzorcev, kot je tehnika ${ }_{4} \mathrm{R}$ ter $\mathrm{ABC}$ povezanosti vedenja in čustvovanja (Rutar Ilc, 2017; Rutar Ilc, Rogič, Ožek, 2017).

\section{Razredne in šolske strategije, ki prispevajo k dobrim odnosom, klimi in vključenosti}

Pokazali smo, kako pomembno vlogo ima učitelj za psihosocialne odnose in vključenost učencev, posredno pa tudi za njihovo počutje in celo dosežke. Pri tem deluje v prvi vrsti s svojim odnosom (odnosno kompetenco), a tudi z vodenjem razreda in s poučevalnim pristopom. Seveda pa so odnosi vzajemni in učitelj ni edini, ki jih gradi in tako prispeva $\mathrm{h} k \mathrm{klimi}$ in I56 
počutju. Velik delež je tudi na strani učencev. Ker pa ti prihajajo v šolo $s$ tem, kar so osvojili in kar utrjujejo v domačem okolju, sta za sporočila o tem, kaj so kakovostni odnosi in kakšne priložnosti za njihovo krepitev učenci dobijo, spet ključna vloga učitelja in vpliv celotne šolske strategije. Priložnosti za sodelovanje ter za čustveno in socialno učenje ali opismenjevanje $\mathrm{v}$ šoli lahko okrepijo socialne veščine ter ustrezno izražanje in uravnavanje čustev pri učencih ali pa celo nadomestijo primanjkljaj iz primarnega socialnega okolja. Učiteljeva vloga in vloga celotnega učiteljskega zbora, podprta z ustreznim ravnateljevim vodenjem, sta nenadomestljivi. Čustveno in socialno opismenjevanje se namreč veliko bolje odvija pod nadzorovanimi pogoji, v premišljenih razrednih in šolskih praksah ter strategijah, kot če je stihijsko ali, še slabše, če se njegove pomembnosti na šoli sploh ne prepozna.

Zato bomo osvetlili, na kakšne načine lahko ob različnih priložnostih, formalnih in neformalnih, strateško in spontano, na sistematičen način $\mathrm{v}$ šolah krepimo dobre odnose, spodbudno in vključujoče učno okolje ter hkrati spodbujamo čustveno in socialno učenje, $s$ tem pa odločilno prispevamo k zmanjšanju možnosti za pojav nasilnega vedenja. Največji vpliv na razredno klimo in na dobro vključenost vseh učencev ima razrednik, vendar z vsem spodaj opisanim lahko prispeva katerikoli učitelj, sproti, nenačrtno ali premišljeno, poglobljeno in sistematično.

Pokazali smo že, kako pomembno je za dobro klimo in počutje ter občutek vključenosti, če učitelj pokaže učencem, da mu je mar zanje, če je spodbuden in jim sporoča, da so $(\mathrm{mu})$ pomembni. Tako rekoč »spotoma « deluje tako s svojo celotno naravnanostjo in odnosom (prej opisano odnosno kompetenco), kot $s$ sporočili in ravnanji, ki dajejo vedeti, kakšno vedenje in kakšni odnosi so zaželeni, kaj se spodbuja, katere vrednote so pomembne in katera prepričanja zaželena, kaj pa je nezaželeno.

Izjemnega pomena so tudi pristni osebni pogovori, pogovori v manjših skupinah in neformalni, spontani stiki z učenci ob različnih priložnostih in iskreno zanimanje zanje. Že mimobežni sprehod po hodniku ima lahko velike učinke. Priložnosti za »spontano « druženje in povezovanje pa predstavljajo tudi ekskurzije, obiski institucij ali dogodkov, tabori, skupne akcije, priprava projektov in raziskovalnih nalog, predstav in dogodkov. Spontani in načrtno, delavniško organizirani pogovori o temah, ki imajo za učence pomen in se nanašajo na njihove želje, interese in potrebe, na njihove skrbi in strahove, so lahko ključni za povezanost učitelja z učenci in učencev med seboj, posledično pa za dobro, vključujočo klimo (Rutar Ilc, 2017; Rutar Ilc, Rogič Ožek, Gramc, 2017).

Razrednik lahko sistematično deluje z razredom pri svojih urah pouka in na razrednih urah ter ob drugih manj formalnih priložnostih. Pri 
pouku predstavljajo najpomembnejše priložnosti različne oblike vrstniškega sodelovanja (npr. skozi formativno spremljanje, pri katerem je vrstniško sodelovanje eden ključnih elementov), s katerim se pri učencih krepi socialne veščine, empatijo in povezanost, pa tudi sodelovalno reševanje problemov, pogajanje in sprejemanje kompromisov, uravnavanje čustev in impulzivnosti, zdravo zavzemanje zase in skupno sprejemanje odločitev.

K dobri razredni klimi prispeva tudi vključevanje učencev $\mathrm{v}$ dogovarjanje o vseh zanje pomembnih zadevah, pa naj gre za odnosno ali učno področje. Tako npr. skupno oblikovanje ali obravnavanje postopkov, pravil in posledic za njihovo kršenje praviloma prispeva $\mathrm{k}$ večji zavzetosti učencev za njihovo upoštevanje in $k$ njihovi večji odgovornosti prav zaradi občutka »lastništva«, ki ga razvijejo $s$ svojim sodelovanjem v procesu dogovarjanja. S spretnim obravnavanjem konfliktov ali s spodbujanjem vrstniške mediacije pa razrednik ne prispeva le k blaženju napetosti, ampak tudi $k$ temu, da učenci sami postopoma usvajajo strategije za reševanje konfliktov. Učence npr. spodbudi k temu, da si v miru prisluhnejo, dojamejo konflikt kot srečanje interesov, a hkrati kot priložnost za pozitivno spremembo, razumejo vlogo čustev $\mathrm{v}$ konfliktih in poiščejo take načine reševanja konfliktov, kjer imata obe strani možnost, da sta slišani ter upoštevani.

Razrednik lahko na razvijanje prosocialnosti oz. socialne in čustvene pismenosti ter na kakovostne vrstniške odnose v svojem razredu na sistematičen način vpliva tudi z izvajanjem delavnic (npr. t. i. socialnih oz. interakcijskih iger), ki prispevajo h krepitvi komunikacijskih veščin in čustvene pismenosti (po katerem od pri nas uveljavljenih in preizkušenih programov, kot so: To sem jaz, Izštekani, Zdrava šola in pilotnega Roka v roki); take delavnice prispevajo tako $\mathrm{k}$ individualnemu čustvenemu in socialnemu opismenjevanju kot tudi $k$ večji povezanosti razreda in sodelovalni kulturi. Dobro počutje vseh je tesno povezano s tem, kako povezan je razred, kako se odvijajo pogovori, koliko in kako so si učenci zmožni prisluhniti, kako rešujejo konflikte, zaradi česar predstavlja enega ključnih varovalnih dejavnikov pred neželenim vedenjem in nasiljem. Pomembni učinki teh aktivnosti in programov so tako na ravni posameznikov (krepitev čustvene in socialne pismenosti) kot na ravni skupine (večja povezanost in sodelovalnost oz. prosocialna naravnanost ter boljša klima). (Več o raziskovalnih podatkih prim. v Kozina et al., 20ı8; Vidmar et al., 20ı8; Tacol et al., 2019, več o samih konkretnih dejavnostih pa v Tacol et al., 2019; Carrell, 2002; Dogša, 1995; Virk-Rode, 1998.)

Aktivnosti, ki jih med drugim lahko izvajamo na razrednih urah ali ob drugih priložnostih, so npr.: pogovori o odnosih, vrednotah in 158 
pogledih, delavnice za komunikacijske veščine in socialne kompetence, učenje asertivnosti, reševanja konfliktov, uravnavanja čustev, krepitev občutka lastne vrednosti in zaupanja v lastne zmožnosti, povečevanje občutljivosti za nasilje in izboljševanje odziva nanj, družbeno odgovorne in trajnostne akcije za vzajemno pomoč ter krepitev sočutja in solidarnosti.

$\mathrm{Za}$ orientacijo pri doseganju želenih dolgoročnih učinkov na področju psihosocialnih odnosov lahko služijo naslednji kriteriji za socialno kompetentnost učencev, ki so močno povezani s kriteriji učne kompetentnosti:

- $\quad$ zmožnost za doseganje ciljev, ki jih pozitivno vrednotijo tako učenci kot vrstniki in učitelji,

- obvladovanje učnih strategij za dosego teh ciljev,

- vzpostavljanje in ohranjanje socialnih odnosov $\mathrm{z}$ drugimi na ustrezen način,

- primerno vedenje,

- prizadevanje za razvoj socialne identitete in občutka pripadnosti ter

- udeležba v skupnih dejavnostih (Peklaj in Pečjak, 2015: 15).

Naj za konec tega razdelka na osnovi vsega zapisanega ovržemo dilemo, ki se v našem šolskem, pa tudi širšem javnem prostoru pojavlja že nekaj časa in je povezana z zatrjevanjem, da se dobro počutje in zahtevno delo v šoli izključujeta. $V$ dosedanjem izvajanju smo skušali dokazati, da je med dobrim počutjem in učno zavzetostjo ter učinkovitostjo pozitivna povezava. Učenci lažje opravljajo zahtevno miselno delo, so bolj zavzeti in se učinkoviteje učijo tedaj, ko se pri tem počutijo dobro, so sprejeti in vključeni, to je, ko izkušajo spodbudno klimo. Pri tem z dobrim počutjem ne mislimo na pasivnost, lenobnost ali podpiranja čutnega ugodja, pač pa ga razumemo kot učinek osmišljenosti znanja in učnih izkušenj, posledično ustrezne zavzetosti za učenje (npr., ko je to dovolj zanimivo in relevantno ter vodeno tako, da terja njihov intelektualni in sploh celostni osebni angažma) in občutka sprejetosti ter zaupanja v lastne zmožnosti, kar je rezultat kakovostnih medsebojnih odnosov in ustreznega vodenja razreda.

\section{Sistematična strategija na ravni šole in celostni model}

Do sedaj smo osvetlili, kako lahko k dobremu počutju in vključujoči klimi, ki deluje preventivno pred različnimi pojavi nasilja, prispeva učitelj tako s svojim odnosom, načinom poučevanja in vodenjem razreda kot s sistematičnim podpiranjem učencev $\mathrm{z}$ različnimi aktivnostmi, ki prispevajo $\mathrm{k}$ medsebojni povezanosti in $\mathrm{h}$ krepitvi čustvene ter socialne pismenosti.

Vse to pa se ne dogaja izolirano, četudi je marsikje žal omejeno samo na posamezne učitelje, ki prepoznavajo vrednost teh praks. Seveda je 
zaželeno, da se te prakse prvenstveno odvijajo $\mathrm{v}$ razredu in $\mathrm{v}$ interakciji učitelja $\mathrm{z}$ učenci. A zares trajnostne, tako za šolsko kulturo nenasilne skupnosti kot za učinkovito čustveno in socialno opismenjevanje ter dolgoročno prevencijo pred nasiljem, so te pobude, če so sistematične, načrtovane in koordinirane na ravni šole in če zajamejo čim več različnih ravni: od pouka od izvenšolskih dejavnosti, od predmetnega do medpredmetnega in kroskurikularnega povezovanja, od razredne do predmetne stopnje, od obveznega do razširjenega programa in od pogovorne do aktivacijske ravni. To terja povezovanje na ravni šole, na ravni celotnega kolektiva in vseh učencev, ter predpostavlja maksimalno možno participacijo (aktivno sodelovanje in prispevek) vseh - učencev in učiteljev. Če želimo, da učenci osvojijo ali upoštevajo določene dogovore, je največja možnost, da se bo to zgodilo, če jih snujemo skupaj z njimi; če želimo, da se v zbornici ne krši določenih pravil, je v ta namen treba delati na vzpostavljanju zaupanja, poglabljanju spoznavanja in izmenjavi pogledov o tem, kaj vsak posameznik potrebuje, da lažje (so)deluje v skupini; če želimo, da bodo starši sodelovali, ne pa »zapovedovali ali odpovedovali«, jih je smiselno k sodelovanju pritegniti, jim ga omogočiti. Ali, kot smo že večkrat napisali v različnih publikacijah ZRSŠ, namenjenih vpeljevanju sprememb na ravni šole: »Ljudje se ne upirajo spremembam. Oni samo ne želijo biti spreminjani, ampak želijo biti vpleteni in imeti vpliv« (Shollaert, 2006 v Pušnik idr. 2006). Kar velja za odrasle, velja tudi za otroke.

Kulturo dobre, zdravo povezane, nenasilne skupnosti ali spodbudno kulturo, torej zaželene oblike kulture skupnosti, gradijo vsi člani. Povezana je $\mathrm{z}$ raziskovanjem stanja in potreb, s skupno izgradnjo vizije, ki vključuje vrednote dobre skupnosti in gradi na zaupanju, sodelovanju in odgovornosti. V zadnjih letih smo izgradnji tovrstne kulture in procesom, potrebnim zanjo, na ZRSŠ posvetili veliko pozornosti tako v projektih (nacionalnih in mednarodnih, npr. Linpilcare in PROLEA) kot v publikacijah, kot so Vpeljevanje sprememb v šole (Pušnik et al., 2007), Ucitelji, raziskovalci lastne prakse (Lesničar et al., 2017) in v petem zvezku že omenjene publikacije Vključujoča šola, z naslovom Tudi učitelji smo učenci (Skvarč, Čuk in Rutar Ilc, 2017). V omenjenih projektih smo preizkušali, $\mathrm{v}$ publikacijah pa predstavili številne participativne pristope za delo v kolektivu in na ravni šole, kot so formati ob že uveljavljenem akcijskem raziskovanju: profesionalni pogovori, reševanje dilem, načrtovanje po GROW, skupno učenje iz virov, učni sprehodi, kritično prijateljevanje, skupne refleksije, t. i. Art of hosting - spodbujanje poglobljenih sodelovalnih procesov. Ti pristopi in z njimi povezana orodja so v pomoč pri vključujočem vodenju skupin in pri spodbujanju sodelovalnih procesov, pri katerih udeleženci sodelujejo $\mathrm{v}$ vseh ključnih fazah osvetljevanja situacije, 
reševanja dilem, načrtovanja in evalviranja, z veliko vmesnega strukturiranega kolegialnega podpiranja (več v Rutar Ilc, Tacer in Žarkovič Adlešič, 2013) in reflektiranja.

$\mathrm{Na}$ tak način lahko učiteljski zbor postopoma, s preudarno vodeni$\mathrm{mi}$ in zato varnimi koraki (od vzpostavljanja začetnega zaupanja, izmenjave potreb, snovanja dogovorov o sodelovanju do načrtovanja in akcijskih načrtov) postavi svojo lastno strategijo krepitve kulture dobre skupnosti ali svoj celostni model na ravni celotne šole (Pečjak, 20I4; Klemenčič et al., 2016). V začetnih poskusih bodo morda šole sistematično delale »le« na krepitvi odnosne kompetence vseh učiteljev in učencev in $\mathrm{v}$ ta namen najprej uporabile zgoraj omenjene opomnike za dobro klimo in disciplino, za učence pa vprašalnike o počutju in ogrodja za pogovore, $v$ nadaljevanju pa pričele intenzivirati izkustvene aktivnosti za pedagoške konference in razredne ure.

Enostaven, časovno obvladljiv, a hkrati zelo učinkovit in trajnosten je lahko pristop sistematičnega vpeljevanja enega od preizkušenih programov čustvenega in socialnega opismenjevanja (npr. To sem jaz Nacionalnega inštituta za javno zdravje ${ }^{2}$ ). Če se na ravni šole sprejme dogovor, da vsak razrednik pri svojih razrednih urah izpelje 5 od to aktivnosti, predstavljenih v priročniku, je v enem letu za razred opravljen pomemben vložek na področju čustvenega in socialnega opismenjevanja. Če se to ponovi vsako leto (delavnice je možno prilagajati starostnim skupinam in jih ponavljati), je lahko - hipotetično - vsak učenec v devetih letih deležen desetin ur čustvenega in socialnega opismenjevanja na premišljen, sistematičen in preizkušen način.

Še ena od preprostejših strategij šol je lahko dogovor za kroskurikularne in medpredmetne povezave na ravni šole. Če vsi učitelji vseh predmetov vsaj v eno uro v vsakem razredu vsaj enkrat na leto (časovno smiselno skoordinirano, tako da so aktivnosti za vsak razred enakomerno razporejene in po možnosti vsebinsko povezane) vključijo na ravni šole dogovorjeno temo čustvenega in socialnega opismenjevanja (npr.: čustva, komunikacijske veščine, zaupanje, samopodoba, vrednote) in jo po svojih močeh (in s pomočjo skupnega usposabljanja) izvedejo, bodo učenci dobili tako znanje kot veščine in izkušnje iz te teme pri več predmetih tekom celega šolskega leta. Seveda bodo nekaterim učiteljem in nekaterim predmetnim področjem te teme in $\mathrm{z}$ njimi povezane veščine bližje, nekaterim pa bolj oddaljene, a v vsakem predmetu je načeloma možno najti izvedbeno obliko (npr. sodelovalno učenje, problemsko nalogo, delo

2 Priročnik ravnokar izhaja v posodobljeni obliki in ga bodo predvidoma prejele vse osnovne šole. 
z viri, izkušenjsko učenje, igro vlog, projekt, raziskavo, članek, ogled filma in pogovor po njem), s katero je možno vsaj posredno podpreti te teme in veščine. Hkrati se skupaj z učenci na tem področju izpopolnjujejo in med seboj povezujejo tudi učitelji.

Končni cilj je, da bi šola v nekaj letih prišla do celovitega in traj(nost) nega modela spodbudnega in varnega učnega okolja oz. kulture nenasilne skupnosti, ki bi zajelo/-a celotno šolo: vse zaposlene, vse učence (torej vse stopnje in vse razrede), vse dele kurikula (obvezni in neobvezni), predmetno, medpredmetno ter kroskurikularno raven, predmetnovsebinsko in metodično didaktično raven, kurikularne in izvenkurikularne aktivnosti, razrede in šolo, skupno in izbirno ponudbo (npr. krožke, tečaje, podporne skupine) in ki bi vključevalo tudi strateško zasnovane družbeno odgovorne projekte, odprte v lokalno skupnost (Klemenčič et al., 2016). Še več, v perspektivi bi se šole lahko povezovale na regijski ravni in z redno izmenjavo izkušenj in intervizijo ustvarile podporno mrežo, ki bi pomagala nadgrajevati obstoječe dobre prakse in opogumljati začetnike, s čimer bi zagotovo lahko prispevale h kulturi nenasilnih odnosov in preprečevanju nasilja ne le pri sebi, ampak tudi v širšem okolju.

\section{Program Spodbudno in varno učno okolje ZRSŠ za usposabljanje šolskih timov}

Na ZRSŠ smo v šolskem letu 20I8/19 pričeli izvajati program Spodbudno in varno učno okolje, namenjen usposabljanju učiteljskih timov in ravnateljev. Program je zasnovan na zgoraj opisanih konceptualnih izhodiščih, za učitelje preprosto predstavljenih in z orodji ter strategijami podprtih v že omenjenem priročniku Vključujoča šola (s poudarkom na 3., 4. in 5. zvez$\mathrm{ku})$. Glavni cilji programa so:

- $\quad$ ozaveščanje o pomenu psihosocialnih odnosov za klimo, počutje in dobro vključenost,

- ozaveščanje o pomenu povezanosti dobrega stika, povezanosti ter občutja kompetentnosti in sprejetosti,

- $\quad$ krepitev odnosne kompetence učiteljev (npr. s pomočjo opomnika za dobro klimo),

- krepitev komunikacijskih veščin učiteljev in učencev,

- osvajanje tehnik in strategij za vzpostavljanje zaupanja in povezanosti med učitelji, med učenci ter med učitelji in učenci,

- dojemanje povezanosti med vedenjem in čustvovanjem (spoznavanje in uporaba $\mathrm{ABC}$ modela ter tehnike $4 \mathrm{R}$ ), 
- $\quad$ razumevanje delovanja čustev in osvajanje osnov čustvene in socialne pismenosti (upoštevaje modele čustvene pismenosti, kot so CASEL, PERMA ipd.),

- osvajanje temeljnih tehnik za čustveno in socialno opismenjevanje (t. i. »mala šola čustvene pismenosti« - kratke izkustvene vaje za samozavedanje, uravnavanje čustev, zavedanje drugih, spoznavanje in povezovanje ...),

- $\quad$ osvajanje zahtevnejših delavničnih formatov za čustveno in socialno opismenjevanje (npr. delavnice za uporabo nedokončanih stavkov in zgodb, dramatizacijo, igro vlog ipd., vse pospremljeno z refleksijami in pogovori).

Program je zasnovan pretežno izkustveno, $z$ veliko vmesnimi vaja$\mathrm{mi}$ (na sebi, s kolegi in z učenci) in refleksijami, vsako novo srečanje pa se prične s predstavitvijo primerov in reševanjem dilem. Prvo leto programa se zaključi s pripravo osnutkov načrtov za celostni pristop k zagotavljanju spodbudnega in varnega okolja na ravni šole. Nadaljnja srečanja pa bodo, kot že omenjeno, podporne narave in bodo namenjena izmenjavi izkušenj, reševanju dilem in interviziji. S programom smo pričeli v štajerski regiji, kjer sodeluje 25 vzgojno-izobraževalnih zavodov (prevladujejo OŠ, nekaj vrtcev in posamezniki iz srednjih šol). Predvidevamo širjenje tudi v druge regije.

\section{Obravnava neželenega in nasilnega vedenja ${ }^{3}$ ter Navodila za ravnanje $v$ primeru nasilja}

Kljub vsem opisanim strategijam in pristopom pa pri nekaterih učencih v šolah še vedno lahko pričakujemo pojav neželenega vedenja, tudi nasilnega. Pri neželenem vedenju razlikujemo med občasnim, še obvladljivim in ponavljajočim se, težje dostopnim neželenim vedenjem. Za ustrezno odzivanje je treba:

I) presoditi resnost in zahtevnost pojava ter temu prilagoditi ukrepe;

2) razumeti neželeno vedenje (kar ne pomeni odobravanja vedenja):

- razloge zanj (npr. utrujenost, dolgčas, pomanjkanje interesa, slabe učne navade, motnje pozornosti, čustvene stiske ...),

- sprožilne situacije in okoliščine, v katerih se pojavlja,

$3 \quad \mathrm{~V}$ ta razdelek so vključena priporočila, ki smo jih v okviru prej omenjenega programa pripravili na ZRSŠ za učitelje za ravnanje v praksi in so tukaj povzeta po internem seminarskem gradivu Rutar Ilc idr., Kako do spodbudnega in varnega ućnega okolja? Odgovori na vprašanja in dileme iz prakse, objavljenem tudi na spletni strani MIZŠ in v reviji Vzgoja in izobraževanje 5 (2018): 57-64. 
- vire in zmožnosti, na katere se lahko opre(mo) pri izboljševanju vedenja,

- pa tudi to, ali učenec ne zna, ne zmore ali noče ravnati drugače (več o tem v Rogič Ožek, 20I8);

3) izbrati ustrezen odziv in načrtovati strategijo (če gre za vedenje, ki ogroža učenca samega, učitelja ali druge učence, je potreben takojšen ustrezno izbran odziv, npr. če gre za nasilno vedenje, je priporočeno ravnanje v skladu z Navodili za ravnanje $v$ primeru nasilja, ki jih je 20I4. pripravil ZRSŠ; če gre za samoogrožujoče vedenje, sta potrebni dodatna zaščita in pomoč s strani svetovalnega delavca; če gre za ponavljajoče se neželeno vedenje, se timsko načrtuje in izvaja individualni načrt za izboljšanje vedenja ).

Ob samem pojavu neželenega vedenja se priporoča naslednje:

I) Če je učenec zmožen in če presodimo, da bo to najbolje, mu ponudimo pogovor o tem, kaj se dogaja,

2) Če bi pogovor na licu mesta prispeval $\mathrm{k}$ burnejšim čustvom, napovemo, da se bomo o tem pogovorili pozneje,

3) Če pa je učenec tako zelo razburjen, da je treba najprej zaščititi njega ali druge, $\mathrm{v}$ vsakem primeru pogovor izvedemo kasneje, ko je v boljšem stanju.

Za pogovore ponavadi upoštevamo načela $4 \mathrm{R}$ ali/in uporabimo sistem $\mathrm{ABC}$, ki pomaga ugotoviti ozadje vedenja in prispeva $\mathrm{k}$ učenju spretnosti za uravnavanje vedenja (več v priročniku Vključujoča šola, 3. in 4. zvezek, ter Rogič Ožek, 2oı8).

$\mathrm{Na}$ kratko povzemamo pravila $4 \mathrm{R}$ odzivanja ob (lažjih) »disciplinskih « težavah/nezaželenem vedenju:

I) Razumno se odzovem: vzdržim se nepremišljenih in impulzivnih odzivov;

2) Razlikujem vedenje od osebe;

3) Razumem dogajanje in ga ne vzamem osebno (kot napad nase), na primer: razumem čustva, ki so za vedenjem, in to pomagam razumeti tudi učencu;

4) Reagiram odločno, a konstruktivno, usmerjeno $v$ rešitve, in spodbujam učenčevo prevzemanje odgovornosti in iskanje nadomestnih vedenj.

Pri pojavu ponavljajočih se blažjih oblik neželenega vedenja lahko učenca na osnovi ugotovitev iz pogovora sistematično podpremo s pomočjo preprostih strategij. Predpostavlja pa se njegova pripravljenost in I64 
zmožnost za sodelovanje. Ob upoštevanju razlogov za neželeno vedenje, ki smo jih ugotovili s pogovorom, z učencem sklenemo dogovor, kako lahko neželeno vedenje izboljša, katera nadomestna vedenja bo za to uporabil in kako mu lahko pomagamo mi kot učitelji (celoten razredni učiteljski zbor usklajeno). Ključno je skozi pogovor:

- $\quad$ pomagati učencu ozavestiti razloge za neželeno vedenje, okoliščine in sprožilce,

- $\quad$ skupaj z njim poiskati nadomestne strategije in vedenja,

- omogočiti čim več priložnosti za krepitev njegovega občutka lastne vrednosti in zaupanja $\mathrm{v}$ lastne zmožnosti.

Pri zahtevnejših oblikah neželenega vedenja, kjer ne pomaga niti prilagajanje potrebam učenca niti stopnjevanje signalov z odločnimi pozivi $\mathrm{k}$ prenehanju oz. k ustreznejšim oblikam vedenja, intervenco naravnamo v skladu s primarnim vzrokom. V primeru ogrožanja sebe in drugih zagotovimo varovanje in se $\mathrm{v}$ skrajnem primeru obrnemo na vodstvo, ki po potrebi kontaktira nujno medicinsko pomoč ter starše. Pomembno je imeti v mislih, da pri učencih s posebnimi potrebami (zlasti pri nevrološki etiologiji) v primerih akutne stiske ne pomaga niti odločno sklicevanje na dogovore niti prijazno prigovarjanje in da v skrajnih primerih ni možno vzpostaviti stika ali pa s svojim ukrepanjem izzovemo še hujšo reakcijo. Intenzivne reakcije so ponavadi kratkotrajne. V umirjenem stanju nato učenca podpremo pri samouravnavanju oz. oblikovanju želenega vedenja, kar je najboljši način tudi za preprečevanje ponovnega pojava neželenega vedenja. Podobno kot pri obravnavi blagih oblik neželenega vedenja ima učenje nadomestnega vedenja dober učinek tudi pri bolj izrazitih oblikah neželenega vedenja. Osnovno načelo je, da učenca naučimo drugačnega odzivanja na sprožilce, ki ima isto funkcijo kot neželeno vedenje, le da je bolj sprejemljivo in da prek njega učenec krepi samouravnavanje (Greene, 1998; Križnar, 2017). V primerih ponavljajočega se neželenega vedenja so potrebni dosledni, usklajeni in ustrezni interventni odzivi, za katere se je priporočljivo vnaprej pripraviti in s sistematičnim timskim pristopom načrtovati dolgoročne (vzgojne) strategije.

Kadar otrok nima odločbe, izkazuje pa opazne čustvene in vedenjske težave in morda že pridobi vzgojni ukrep (OŠ), strokovni tim izdela individualni oz. individualizirani vzgojni načrt za delo z njim. V skladu z učenčevim sodelovanjem (in v skladu z njegovimi zmožnostmi) se v njem opredeli načrt podpore socialno sprejemljivemu vedenju. $V$ tem načrtu preučimo sprožilce, okoliščine in odzive okolja ter po potrebi vplivamo nanje ter jih spreminjamo (povzeto po internem seminarskem gradivu Rutar Ilc idr., Kako do spodbudnega in varnega učnega okolja? Odgovori 
na vprašanja in dileme iz prakse, objavljenem tudi na spletni strani MIZŠ in v reviji Vzgoja in izobraževanje, 2018).

\section{Zaključek}

V prispevku utemeljimo, da je najbolj učinkovito ravnanje v zvezi z nasiljem preventivno. Pri tem preventivo razumemo v najširšem smislu, torej ne le kot ozaveščanje o nasilju in preventivne delavnice na to temo, pač pa kot gradnjo kulture dobre skupnosti, ki temelji na zdravih psihosocialnih odnosih ter razviti odnosni kompetenci ter čustveni in socialni kompetentnosti učiteljev in učencev. $\mathrm{V}$ ta namen je najbolj učinkovita usklajena, vključujoča strategija na ravni celotne šole, ki prežema kurikularne in izvenkurikularne dejavnosti.

\section{Literatura}

Bluestein, J. (1998) Disciplina 2I. stoletja. Ljubljana, Zavod RS za šolstvo.

Carrell, S. (2002) Skupinske aktivnosti za mladostnike: Priročnik za vodenje skupin. Ljubljana: Inštitut za psihologijo osebnosti.

Dogša, I. (1995) Interakcijske vaje za mladostnike. Ljubljana: Zavod RS za šolstvo.

Holcar, A., idr (2016) Formativno spremljanje v podporo učenju. Ljubljana: Zavod RS za šolstvo.

Greene, R. W. (1999) Eksplozivni otrok. Nov pristop k razumevanju in ravnanju skronično neprilagodljivimi otroki. Ljubljana: Orbis.

Holcar, A., in Kregar, S. (2019) Glas učenca in formativno spremljanje, Vzgoja in izobraževanje 2-3, str. 7-13.

Juul, J. (2014) Šolski infarkt. Kaj labko storimo, da bo šlo otrokom, staršem in učiteljem bolje. Celovec: Mohorjeva družba.

Klemenčič, I., idr. (2016) Preventivne dejavnosti sistemskega pristopa k medvrstniškemu nasilju v VIZ. V: Sistemski pristop k medvrstniškemu nasilju v vzgojno-izobraževalnih zavodih. Ljubljana: Inštitut za kriminologijo

Kyriacou, C. (2010) Odnosi z učenci, Vzgoja in izobraževanje 5, str. 45-55.

Košir, K. (2013) Psihosocialni odnosi v šoli. Maribor: Pedagoška fakulteta Univerze v Mariboru.

Kozina, A., idr. (2018) Kako do spodbudne in vključujoče razredne klime z razvijanjem empatije? Vzgoja in izobraževanje 5, str. I0-17.

Križnar, S. (ur.) (2017) Motnje vedenja pri otrocih in kako preživeti? Primeri uspešnih praks $v$ osnovnih šolah. Ljubljana: Supra.

Kroflič, R. (2013) Krepitev odgovornosti v šolski skupnosti med konceptoma državljanske in moralne vzgoje, Sodobna pedagogika 64(2). 
Kroflič, R. (2010) Dialoški model avtoritete kot spopad za vzajemno pripoznanje, Sodobna pedagogika, 6I(3), str. 134-154.

Kroflič, R. (20II) Induktivni vzgojni pristop. Sekcija MVO pri Društvu specialnih in rehabilitacijskih pedagogov Slovenije. Rogaška Slatina, april 2011.

Malešević, T. (2018) Pomen dobrih socialnih odnosov med učitelji in učenci in učiteljeve odnosne kompetence. Vzgoja in izobraževanje 5, str. 17-25.

Marzano, R., in Marzano, J. S. (2010) Ključ do vodenja razreda. Vzgoja in izobraževanje 5, str. 55-62.

Marzano, R. J., in Simms, J. A. (2013) Coaching Classroom Instruction. Bloomington, Marzano Research Laboratory.

Muršič, M. (ur.) (20I2) (O)krog nasilja v družini in šoli. Ljubljana: Inštitut za kriminologijo pri Pravni fakulteti v Ljubljani.

Pečjak, S. (20I4) Medvrstniško nasilje v šoli. Ljubljana: Znanstvena založba FF.

Peklaj, C., in Pečjak, S. (2015) Psihosocialni odnosi v šoli. Ljubljana: Znanstvena založba FF.

Pšunder, M. (2004) Disciplina v šoli. Ljubljana, Zavod RS za šolstvo.

Pšunder, M. (20II) Vodenje razreda. Maribor, Mednarodna Založba Oddelka za slovanske jezike in književnost, Filozofska fakulteta.

Pušnik, M. (2007) Vpeljevanje spremembe v šole. Priročnik za šolske razvojne time. Ljubljana: ZRSŠ.

Rogič Ožek, S. (20I8) Čustveno opismenjevanje v vzgojno-izobraževalnih procesih. V Učiteljev glas, priloga revije Vzgoja in izobraževanje 5, str. 4-I2.

Rutar Ilc, Z. (2017) Vodenje razreda za dobro klimo in vključenost. Ljubljana: ZRSS

Rutar Ilc, Z., Rogič Ožek, S., Gramc, J. (2017) Socialno in čustveno opismenjevanje za boljšo vključenost. Ljubljana: ZRSŠ.

Skvarč, M., Čuk, A., Rutar Ilc, Z. (20I7) Tudi učitelji smo učenci. Ljubljana: ZRSS̆

Tacol, A., idr. (2019) To sem jaz. Priroćnik za delo z razredom in zdravo odraščanje. Celje, Nacionalni inštitut za javno zdravje. (Prenovljena izdaja)

Virk-Rode, J., idr. (1998) Socialne igrev osnovni šoli. Ljubljana: ZRSŠ.

Vidmar, M., idr. (2018) Čustvene in socialne kompetence strokovnih delavcev: (spregledani) dejavnik v razvoju strokovnih delavcev ter učencev, Učiteljev glas, priloga revije Vzgoja in izobraževanje 5, str. 18-26. 